\title{
Operando observation of nickel/ ceria electrode surfaces during intermediate temperature steam electrolysis
}

Vasiliki Papaefthimiou, ${ }^{a}$ Dimitris K. Niakolas, ${ }^{b}$ Fotios Paloukis, ${ }^{a}$ Detre Teschner, ${ }^{c}$ Axel Knop-Gericke, ${ }^{c}$ Michael Haevecker, ${ }^{c, d}$ and Spyridon Zafeiratos*a

*spiros.zafeiratos@unistra.fr

alnstitut de Chimie et Procédés pour l'Energie, I'Environnement et la Santé (ICPEES), ECPM, UMR 7515 CNRS-Université de Strasbourg, 25, rue Becquerel, 67087 Strasbourg Cedex 02, France. E-mail: spiros.zafeiratos@unistra.fr

bFORTH/ICE-HT, GR-26504 Rion (Patras), Greece.

CFritz-Haber-Institut der M PG, Faradayweg 4-6, D-14195 Berlin, Germany.

dEnergy Conversion, Stiftstr. 34-36, 45470 M uelheim a.d. Ruhr, Germany.

\begin{abstract}
The solid oxide electrolysis cell (SOEC) technology has a huge potential for future mass production of hydrogen, mainly due to its high electrical-to-chemical energy conversion efficiency. However, the durability and the performance of SOEC devices are inferior to that of other competitive electrolysis technologies inhibiting the commercialization of SOECs. Despite the fact that Ni-based cermets are currently the most widely used cathode materials for SOEC, change of the nickel oxidation state has been accused as a major issue limiting the performance of these devices. In this work we provide operando experimental evidence of the active surface oxidation state and composition of nickel/doped-ceria cermets under water electrolysis conditions using ambient pressure X-ray photoelectron and near edge X-ray absorption fine structure spectroscopies, combined with quantitative spectra simulation. Remarkably under specific operational conditions, nickel is maintained in a partially oxidized state which, counterintuitive to the expected behavior, can be beneficial to the cell performance. This finding may initiate new improvement strategies for SOEC electrodes based on thorough optimization of the operational conditions, in order to engineer in situ the most propitious electrode configuration.
\end{abstract}

\section{Introduction}

Renewable electricity sources, such as wind and solar, are usually intermittent in the sense that are difficult to predict and are not continuously available. This fact points to the necessity of efficient technologies to store energy and in particular electricity, during power peak loads by converting it into another energy form. An attractive option is the conversion of electricity to chemical energy, 
which could be stored in large amounts and for long periods. Hydrogen is likely the most attractive chemical for this process and can be locally generated by electrolysis of water using intermittent excess solar or wind power [1].. Water electrolysis can be carried out at low temperature, where $\mathrm{H}_{2} \mathrm{O}$ is in its liquid form [2,3], using alkaline or proton exchange membrane electrolysers that can achieve energy efficiencies of about 75\% [4]. Alternatively can be also performed at high temperature (above $500{ }^{\circ} \mathrm{C}$ ) with steam, by using Solid Oxide Electrolysis Cells, (SOECs) [4-8]. Although low temperature electrolysis is a well-established technology [4], SOEC devices have enormous potential for future mass production of hydrogen and show great dynamics to become commercially competitive [6],[7],[9]. The main reason is the fact that by increasing the operating temperature the demand of electrical energy is significantly reduced and in some cases the electrical-to-chemical energy conversion efficiency can exceed $100 \%$. This can lead to a reduced cost of hydrogen production, especially if the required heat energy is provided by Joule heat that is inevitably produced by the internal electrical resistance of the cell, or by waste heat of high-temperature industries [4],[7].

In order to increase the commercial competitiveness of the SOEC technology, the performance and durability of the currently tested devices should be improved. Although operating a SOEC device at very high temperatures $\left(800-1000^{\circ} \mathrm{C}\right)$ is advantageous from the thermodynamics point of view, in long term operation the degradation of the cell is accelerated due to materials failure. The term degradation usually refers to both performance degradation and irreversible mechanical failure such as electrode delamination from the electrolyte. As a consequence, lowering the operation temperature, by the development of the so-called intermediate temperature SOECS (IT-SOECS), can maintain material stability and increase the device lifetime [10],[11]. Doped-ceria (cerium oxide or $\mathrm{CeO}_{2}$ ) and in particular, $\mathrm{Gd}$-doped ceria (GDC) exhibits one of the highest ionic conductivities and good application potential among all doped ceria types [12],[13]. Doped ceria does not only act as a charge carrier but it is also electrochemically active [14]. In practical applications, mixing ceria with metals (typically nickel) provides the adequate electronic and ionic conductivities as well as the electrocatalytic activity at intermediate temperatures, which is an ideal combination for the fuel (steam) electrode in IT-SOECS [15],[16]. Recently, the use of Ni/GDC as an electrode component in SOECs with enhanced performance has been demonstrated [17],[18].

Despite the beneficial effect of IT-SOECs due to lower thermo-mechanical stress of the cell materials, SOEC performance (cell or stacks) is still susceptible to degradation due to the modification of both fuel and oxygen electrodes. Concerning Ni-containing fuel electrodes, oxidation, coarsening and volatilization of nickel have been proposed as primarily causes of the cathode failure and cell deactivation [19],[20]. Oxidation of nickel not only reduces the electronic conductivity, but can also induce stress on the cathode due to volumetric expansion [21], leading to crack formation and 
irreversible cell failure [20],[22]. In addition, nickel coarsening is associated with decrease of the three-phase boundary (TPB) length and increase of the cell losses [23],[24].

Kinetic models are typically employed in order to describe the catalytic and electrocatalytic performance of operating electrodes [25], [26]. However it is critical to correlate the performance with the chemical and structural characteristics of the electrodes under operation conditions and in real time. This is because the application of the electrochemical potential can induce surface restructuring of the electrodes, which is affecting their catalytic performance [9]. Since electrochemistry takes place at TPB between electrode, electrolyte and gas, methods particularly sensitive to this area are needed [27]. Therefore, there is an ongoing effort to understand the performance of the electrode materials by analyzing in situ, model solid oxide electrochemical cells using operando X-ray photoelectron spectroscopy [28, 29],[30],[31],[32],[33, 34]. Realistic Ni-ceria cermet electrodes are much less studied by this approach[35] despite their high relevance to practical applications. The dominant concepts which correlate nickel oxidation with cell degradation are mainly deduced from electrochemical (e.g. impedance spectroscopy) or post-mortem electrode characterization [36].

Recently we have reported on the effect of humid gas environment on the oxidation state and composition of Ni/GDC electrodes [37]. In this work we present a detailed spectroscopic investigation on the surface composition and oxidation state of the Ni-ceria fuel electrode during water electrolysis. We show that the surface of the electrode during steam electrolysis is determined by a complex interplay between the thermochemical oxidation due to water vapor and the electrochemical reduction of nickel. In contrast to the common conception we provide a new paradigm, which demonstrates that nickel oxide is not always detrimental for the electrode performance, but in some cases it can be also beneficial for its stability.

\section{Experimental Section}

The details of the sample preparation have been described elsewhere. [38]. The SOEC consisted of a $80 \mu \mathrm{m} \mathrm{NiO} / \mathrm{Gd}_{0.1} \mathrm{Ce}_{0.9} \mathrm{O}_{2}$ (65/35 wt.\% ratio) functional layer as the working electrode on a $300 \mu \mathrm{m}$ thick YSZ electrolyte and a magnetron sputtering deposited Pt layer on the reverse side acting as the counter electrode. The samples were sintered in air at $1250{ }^{\circ} \mathrm{C}$ for 5 hours. In situ ambient pressure $X$-ray photoelectron and near edge absorption fine structure spectroscopies (APXPS and NEXAFS, respectively) were performed at ISISS beamline at BESSY synchrotron radiation facility at the Helmholtz- Zentrum-Berlin [39]. SOEC samples of about $36 \mathrm{~mm}^{2}$ area were mounted between two stainless steel clamps (the one at the top with a $4 \mathrm{~mm}$ diameter slit) and heated from the rear using an IR-laser. The stainless steel clamps were also used as the current collectors. The temperature was 
controlled by a K-type thermocouple mounted on the side of the sample. The gas flow into the reaction cell was controlled by mass flow controllers and the gas phase was monitored by an online quadrupole mass spectrometer (QMS). Electrical potentials were applied between the working and the counter electrodes and the current flow was measured using a computer controlled $\mu$ Autolab potensiostal/galvanostat. The working electrode was grounded and the bias voltage was applied on the counter electrode. It should be noted that under water electrolysis conditions oxide ions in the YSZ electrolyte move from the Ni-GDC cathode toward the anode (Pt film). Initial annealing of the sample in 0.2 mbar $\mathrm{O}_{2}$ was used to eliminate residual carbon from the surface and after this procedure the $\mathrm{C}$ 1s signal was within the noise level during all experiments. The stability of the surface was verified by repeating Ce $3 d$ and Ni $2 p$ APXPS spectra at the beginning and the end of the applied potential period. The degradation of the cell in the course of experiment was examined by repeating identical cell conditions (applied voltage, ambience and temperature) between various samples treatments. By these tests it was revealed that the observed decrease of the cell current was about $1 \%$ per hour ( $5 \%$ drop after about 6 hours). Finally, we tested for possible photon beam effects by shifting the analysis spot to a new sample position during measurements, but no major differences were detected in the spectra indicating X-ray beam stability and homogeneity of the samples. The samples did not exhibit any electrostatic charging under open circuit conditions and the binding energies (BES) are presented as measured without any correction. Application of a potential difference between the working (Ni/GDC) and counter (Pt) electrodes shifts the APXPS peaks as has been described earlier [29]. The presented BE shifts are calculated in respect to the BE measured at open circuit (without voltage application). The mean valence values of nickel and cerium were obtained from the average oxidation state of metal and metal oxide content. Long term experiments indicated a gradual drop of the Ni $2 p$ to Ce $3 d$ APXPS peak area ratio as a function of time. This drop was almost linear and of about $1.5 \%$ of the initial $\mathrm{Ni} / \mathrm{Ce}$ ratio per hour. The XPS element intensities were simulated by SESSA vs.2.0 software [40] using a sample spherical particles model. In case of non-overlapping particles it was assumed that the emitted photo-electrons of nickel and ceria do not interact. A Shirley background subtraction was used to estimate the peak area ratio and the quantitative calculations were performed taking into account the photon flux, the photon-energy and the photo-ionization cross-sections dependence of the atomic subshells [41]. The NEXAFS spectra were recorded in the Total Electron Yield (TEY) mode. The surface morphology before and after the treatments in the spectrometer was inspected by scanning electron microscopy using a Jeol JSM -6700F microscope.

\section{Results}




\subsection{Steam electrolysis.}

Preparation of SOEC cathodes involves high temperature sintering in air $\left(>1000^{\circ} \mathrm{C}\right)$ which results in an oxidized electrode. Reduction is achieved either by $\mathrm{H}_{2}$ pretreatment [42] or more commonly steam is mixed with hydrogen [18],[43], despite the fact that $100 \%$ steam feed gives the optimum SOEC efficiency. In our previous work we found partial oxidation of pre-reduced Ni/GDC electrodes exposed to $100 \%$ steam at open circuit (O.C.)[37] which is also clearly demonstrated here (supporting information 1). To identify the nature of the oxidized Ni phase, the Ni $2 p_{3 / 2}$ photoelectron and $X$-ray absorption spectra of $\mathrm{Ni} / \mathrm{GDC}$ in $\mathrm{H}_{2} \mathrm{O}$ are compared with those of a reference $\mathrm{NiO}$ sample in supporting information 2. The similarity of APXPS spectra in the two cases suggests that within 2 hours under $\mathrm{H}_{2} \mathrm{O}$ the pre-reduced nickel of $\mathrm{Ni} / \mathrm{GDC}$ undergoes thermochemical oxidation by the steam fuel [44]:

$$
\mathrm{Ni}+\mathrm{H}_{2} \mathrm{O} \neq \mathrm{NiO}+\mathrm{H}_{2}
$$

However, close inspection of the NEXAFS spectra and in particular of the $L_{2}$-edge (see inset of figure S2), reveals a marginal increase of the peak feature around $872 \mathrm{eV}$ in case of Ni/GDC. In previous works[45],[46] the increase of the peak at $872 \mathrm{eV}$ was attributed to the appearance of $\mathrm{Ni}^{3+}$ species. Therefore although the $\mathrm{NiO}\left(\mathrm{Ni}^{2+}\right)$ is the main oxidation state of $\mathrm{Ni} / \mathrm{GDC}$ electrodes in $\mathrm{H}_{2} \mathrm{O}$, one cannot exclude the potential presence of $\mathrm{Ni}^{3+}$ ions which might arise either due to defects in $\mathrm{NiO}$ [47] or from oxyhydroxide species[48]. Nevertheless, for brevity the oxide formed over Ni/GDC electrode will be referred to as $\mathrm{NiO}$. It should be noted that in $\mathrm{H}_{2} \mathrm{O} / \mathrm{H}_{2}$ fuel (mixture $1: 1$ ) immediate reduction of $\mathrm{NiO}$ to metallic $\mathrm{Ni}$, as well as further reduction of ceria, are demonstrated in the APXPS and NEXAFS spectra (supporting information S3a). Since the NEXAFS spectra analysis depth is about $5 \mathrm{~nm}$ (figure S3b), the reduction is expected to extent in several surface layers. In addition, the fast reduction of surface $\mathrm{NiO}$ in the $\mathrm{H}_{2} \mathrm{O} / \mathrm{H}_{2}$ mixture justifies the common strategy in SOEC technology to co-feed $\mathrm{H}_{2}$ with $\mathrm{H}_{2} \mathrm{O}$ in order to maintain nickel in a reduced state.

The electrochemical response of the pre-reduced electrode upon step polarization in $100 \% \mathrm{H}_{2} \mathrm{O}$ is shown in Fig. 1a. Indicatively, the zero values at O.C. are attributed to the fact that both electrodes (working and counter) face the same gas conditions. The current density increases monotonically with the cell bias (the indicated current density was measured after about 20 min at each bias voltage), but lower currents were measured in the downward cycle as compared to these at upward. An overall current density loss of about $5 \%$ (star-point in fig. 1a) was found by repeating the steam polarization experiment, after about 8 hours of operation. This indicates that the observed current changes between upward and downward cycles shown in fig. 1a (with time difference of about 2 hours), are to a large extent reversible, and are not caused by irreversible cell degradation. 
It is clear that in the absence of a reference electrode the total cell voltage in the I-V curves of Fig. 1a, do not reflect directly the overpotential of the working electrode (Ni/GDC), but contains also the voltage drop of the counter electrode (Pt), as well as the ohmic voltage drop in the electrolyte (YSZ). However, as Zhang et al.[28] have demonstrated, the overpotential of the working electrode is followed by the BE shifts of APXPS spectra. At the inset of fig. la we show the evolution of the cell current as a function of the mean BE shift obtained by the $01 \mathrm{~s}$, Ce $3 \mathrm{~d}$ and Ni $2 \mathrm{p}$ APXPS spectra, at each applied potential. The small magnitude of the BE shift (meV) suggests significant potential losses at the Pt/YSZ interface and in the electrolyte. However, as can be seen the systematically lower currents at the downward cycle are reproduced in this graph, allowing correlating the chemical state and surface composition with the electrochemical performance.

Operando APXPS results show that the ceria oxidation state is not modified under bias (supporting information 4). On the contrary, $\mathrm{NiO}$ undergoes partial reduction starting at $-0.8 \mathrm{~V}$, where the current density is approximately $30 \mathrm{~mA} / \mathrm{cm}^{2}$. The partial reduction of $\mathrm{NiO}$ is enhanced at $-1 \mathrm{~V}$, while upon further bias to $-1.3 \mathrm{~V}$ it is fully reduced and subsequently remains to the metallic state even when the potential is stepped backwards (see supporting information 4). The reduction of $\mathrm{NiO}$ upon bias is not abrupt, but progressive as indicated by the modifications in the $\mathrm{Ni} 2 \mathrm{p}$ spectrum recorded at different time intervals at $-1 \mathrm{~V}$ (see supporting information 5). However, supporting information 5 shows that, just after bias the current density is disproportionally high compared to gas phase $\mathrm{H}_{2}$ production. This suggests that water electrolysis cannot be the sole process for the high currents observed at the initial stages. Thereby, the initial high currents should be related to the electrochemical reduction of $\mathrm{NiO}$ to $\mathrm{Ni}$ (eq. 2) [49], which competes to the thermochemical Ni oxidation by the steam (eq. 1).

$$
\mathrm{NiO}+2 \mathrm{e} \ddagger \mathrm{Ni}+\mathrm{O}^{2-}
$$

The modification in the oxidation state of nickel and cerium may conveniently be expressed by the mean valence numbers $x$ and $y$ which were calculated after deconvolution of the $\mathrm{Ni} 2 \mathrm{p}$ and $\mathrm{Ce} 3 \mathrm{~d}$ photoelectron peaks respectively (supporting information 6). In fig. 1b, the oxidation state of nickel as a function of the measured cell current at various applied potentials (represented in different color zones) is shown. In general can be noticed that above $-1 \mathrm{~V}$, nickel is metallic, while at $-1 \mathrm{~V}$ and below nickel is partly oxidized but the cell seems not to be deactivated.

Apart from nickel oxidation state, the electrocatalytic performance is influenced by coarsening of nickel particles, which has been associated with a decrease of the TPB length [23]. Modifications of the electrode surface morphology, i.e. nickel coarsening, are reflected in our experiment by the changes in the $\mathrm{Ni} 2 \mathrm{p}$ and $\mathrm{Ce} 3 \mathrm{~d}$ peak area ratio (Ni/Ce AR) [50],[51]. In fig. 1c a direct correlation between the $\mathrm{Ni} / \mathrm{Ce} \mathrm{AR}$ and the cell current is established for multiple measurements performed at the same potential. In particular, the higher the Ni/Ce AR, the higher the cell current at constant voltage, regardless of the nickel oxidation state (e.g. at $-1 \mathrm{~V}$ ). This result can explain the 
systematically lower current observed in the downward potential cycle as compared to the upward (see blue arrows) shown in fig. 1a. Reduction of nickel at high potentials provoke lower $\mathrm{Ni} / \mathrm{Ce}$ ARs [35] and deteriorate the cathode performance, probably by decreasing the TPB length.
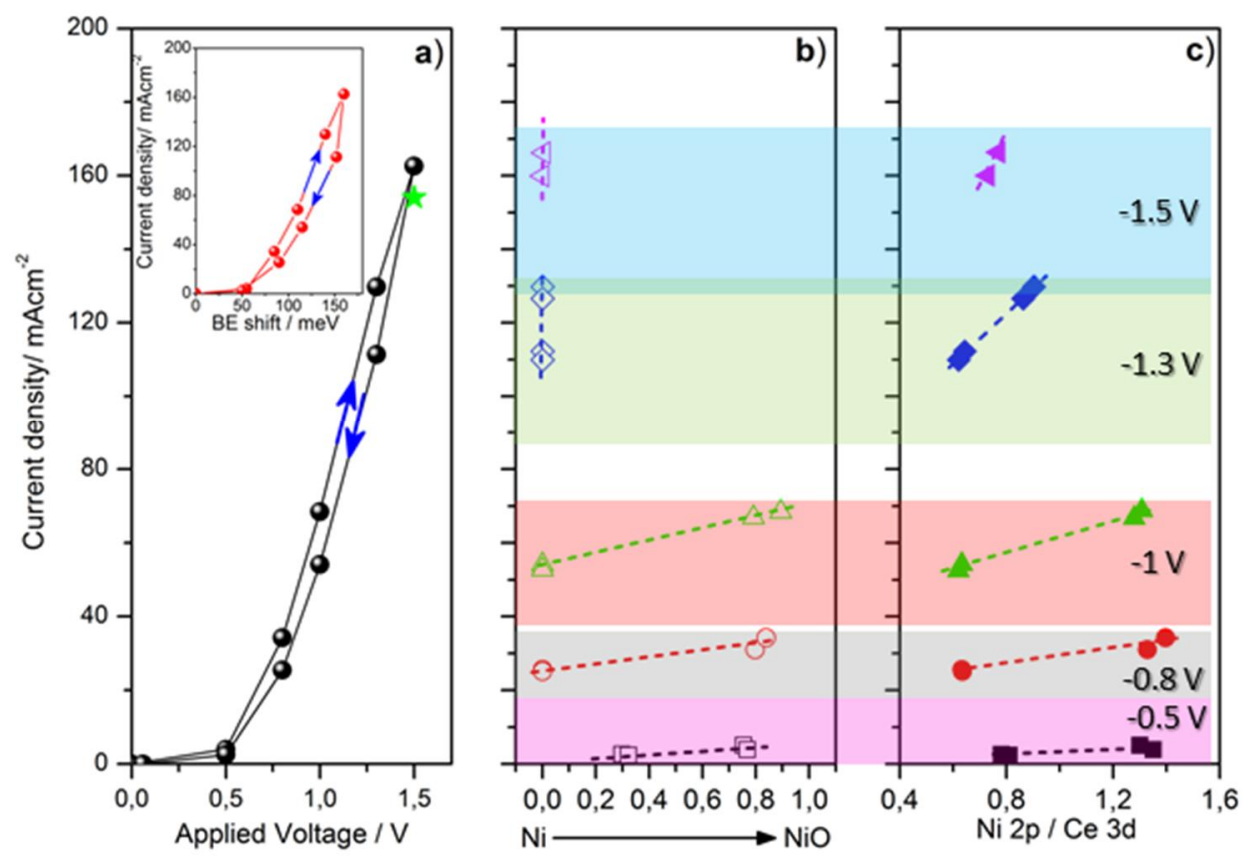

Figure 1. a) I-V polarization curves for $\mathrm{Ni} / \mathrm{GDC}$ electrode under $\mathrm{H}_{2} \mathrm{O}$ feed recorded in potential step-up and down cycles. The green-star represents the cell current measured in $\mathrm{H}_{2} \mathrm{O}$ after 8 hours of operation. The inset shows the same I-V curve, except that the applied voltage has been replaced by the binding energy shift of the APXPS spectra between $0 \mathrm{~V}$ and each applied voltage. The current density for various applied potentials as a function of: b) $\mathrm{NiO}_{x}$ valence and c) $\mathrm{Ni} / \mathrm{Ce}$ AR measured by APXPS. The colour zones represent the applied potentials. Prior to the potential application the sample was pretreated in $\mathrm{H}_{2}$ and remained at O.C. in the feed gas for about 30 min. The voltage was applied directly between the working (Ni/GDC) and the counter (Pt) electrodes.

As shown in fig. 1b, when the cell is operating at high voltages (>-1V) nickel oxide is transformed to metallic nickel. In this case, introduction of $\mathrm{H}_{2}$ has no effect on the nickel surface oxidation state, as is commonly alleged, but still affects the oxidation state of ceria. In supporting information 6 we compare the $\mathrm{Ce} 3 \mathrm{~d}$ core level spectra under cathodic polarization (-1.5 V) in $100 \% \mathrm{H}_{2} \mathrm{O}$ and $\mathrm{H}_{2} / \mathrm{H}_{2} \mathrm{O}$ atmospheres. In addition, in order to assess the reversibility of the modifications, the sample at the end was exposed to $\mathrm{O}_{2}$. Based on these spectra we calculated the $\mathrm{Ni} / \mathrm{Ce} \mathrm{AR}, \mathrm{NiO}_{x}$ and $\mathrm{CeO}_{y}$ valences presented in Table 1, which show that the composition of the fuel has a profound effect on the ceria oxidation state and the ARs. In particular, as compared to $100 \% \mathrm{H}_{2} \mathrm{O}$, ceria is further reduced with the 
introduction of $\mathrm{H}_{2}$, but more importantly the $\mathrm{Ni} / \mathrm{Ce}$ ratio drastically decreases as the atmosphere becomes more reductive. This procedure is partially reversible and subsequent exposure of the electrode to $\mathrm{O}_{2}$ re-oxidizes the surface and partly restores the $\mathrm{Ni} / \mathrm{Ce}$ ratio. The observed surface rearrangement due to re-oxidation should be taken into account when results are obtained by postmortem analysis of the electrodes, which is a common practice in SOEA studies.

Table 1. The Ni/Ce AR and the $\mathrm{CeO}_{y}, \mathrm{NiO}_{x}$ mean valences

\begin{tabular}{|c|c|c|c|}
\hline $\begin{array}{c}\text { Conditions } \\
\left(700^{\circ} \mathrm{C}, 0.2 \mathrm{mbar}\right)^{[\mathrm{a}]}\end{array}$ & $\mathrm{Ni} 2 \mathrm{p} / \mathrm{Ce} 3 \mathrm{~d} A R^{[b]}$ & $\begin{array}{c}\mathrm{CeO}_{\mathrm{y}} \\
\text { stoichiometry }\end{array}$ & $\begin{array}{c}\qquad \mathrm{NiO}_{x} \\
\text { stoichiometry }{ }^{[b]}\end{array}$ \\
\hline $\mathrm{H}_{2} \mathrm{O}$ & 0.94 & 1.71 & 0 \\
\hline $\mathrm{H}_{2} / \mathrm{H}_{2} \mathrm{O}$ & 0.46 & 1.67 & 0 \\
\hline $\mathrm{H}_{2}$ & 0.38 & 1.5 & 0 \\
\hline $\mathrm{O}_{2}$ & 0.82 & 2 & 1 \\
\hline
\end{tabular}

[a] Experiments were performed consecutively starting in $\mathrm{H}_{2} \mathrm{O}$ and ending in $\mathrm{O}_{2}$ ambient on the same sample within a 12 hour period. ${ }^{[b]}$ Calculated from the $\mathrm{Ni} 2 \mathrm{p}$ and $\mathrm{Ce} 3 \mathrm{~d}$ APXPS spectra (hv= $1350 \mathrm{eV}$ ) at $700{ }^{\circ} \mathrm{C}$ and under $-1.5 \mathrm{~V}\left(\mathrm{H}_{2} \mathrm{O}, \mathrm{H}_{2} / \mathrm{H}_{2} \mathrm{O}\right.$, $\mathrm{H}_{2}$ ) or O.C. $\left(\mathrm{O}_{2}\right)$.

\subsection{Reversible redox kinetics of Ni/ GDC under cathodic and anodic polarization in steam.}

As shown above, partially oxidized nickel improves the cell performance (e.g. see fig. $1 \mathrm{~b}$ at $-1 \mathrm{~V}$ ), which is counterintuitive to the expected detrimental effect on the basis of NiO's poor electronic conductivity and its low activity for water dissociation (the first step of the electrolysis) [4]. To rationalize this striking observation, the electrode was further studied in $100 \% \mathrm{H}_{2} \mathrm{O}$ environment at -1 $\mathrm{V}$, where the partially oxidized nickel state is observed. Measurements were performed at lower temperature $\left(500{ }^{\circ} \mathrm{C}\right)$, in order to slow down the $\mathrm{Ni} / \mathrm{NiO}$ transformation kinetics and allow monitoring them by APXPS. As expected, both cell current and $\mathrm{H}_{2}$ production at $500{ }^{\circ} \mathrm{C}$ were substantially lower as compared to those at $700{ }^{\circ} \mathrm{C}$.

Fig. 2a shows time-dependent $\mathrm{Ce} 3 \mathrm{~d}$ and $\mathrm{Ni} 2 \mathrm{p}_{3 / 2}$ spectra recorded initially at $-1 \mathrm{~V}$ and subsequently under $+1 \mathrm{~V}$. The Ce $3 \mathrm{~d}$ spectra remain identical, whereas the metallic $\mathrm{Ni} 2 \mathrm{p}_{3 / 2}$ component at $852.6 \mathrm{eV}$ appears at cathodic polarization (-1 V), but $\mathrm{Ni}$ is oxidized back to its initial state when the polarity is inversed. Fig. $2 \mathrm{~b}$ shows the evolution of the nickel and cerium mean valence as a function of bias and time. After a short induction period, there is an almost logarithmic decay of nickel valence, which finally stabilizes at $\mathrm{NiO}_{0.5}$ after a period of 3 hours. Under reverse polarization $(+1 \mathrm{~V})$, reoxidation to $\mathrm{NiO}$ is observed with a higher, almost linear, rate as compared to the reduction step. The Ce $3 \mathrm{~d}$ 
spectra are invariant under either polarization. The modification of the surface composition during the bias-induced redox process is shown in Fig. 2c. Reduction of $\mathrm{NiO}$ (at $-1 \mathrm{~V}$ ) led to the decrease of the $\mathrm{Ni} / \mathrm{Ce} \mathrm{AR}$, followed by an equivalent decrease of the cell current in line with the observations in fig. 1c. On the other hand, when the polarization was reversed, nickel was reoxidized and the $\mathrm{Ni} / \mathrm{Ce}$ AR was reestablished back to its initial value. In this case the measured cell current had a reverse polarity and was about one order of magnitude lower (not shown).

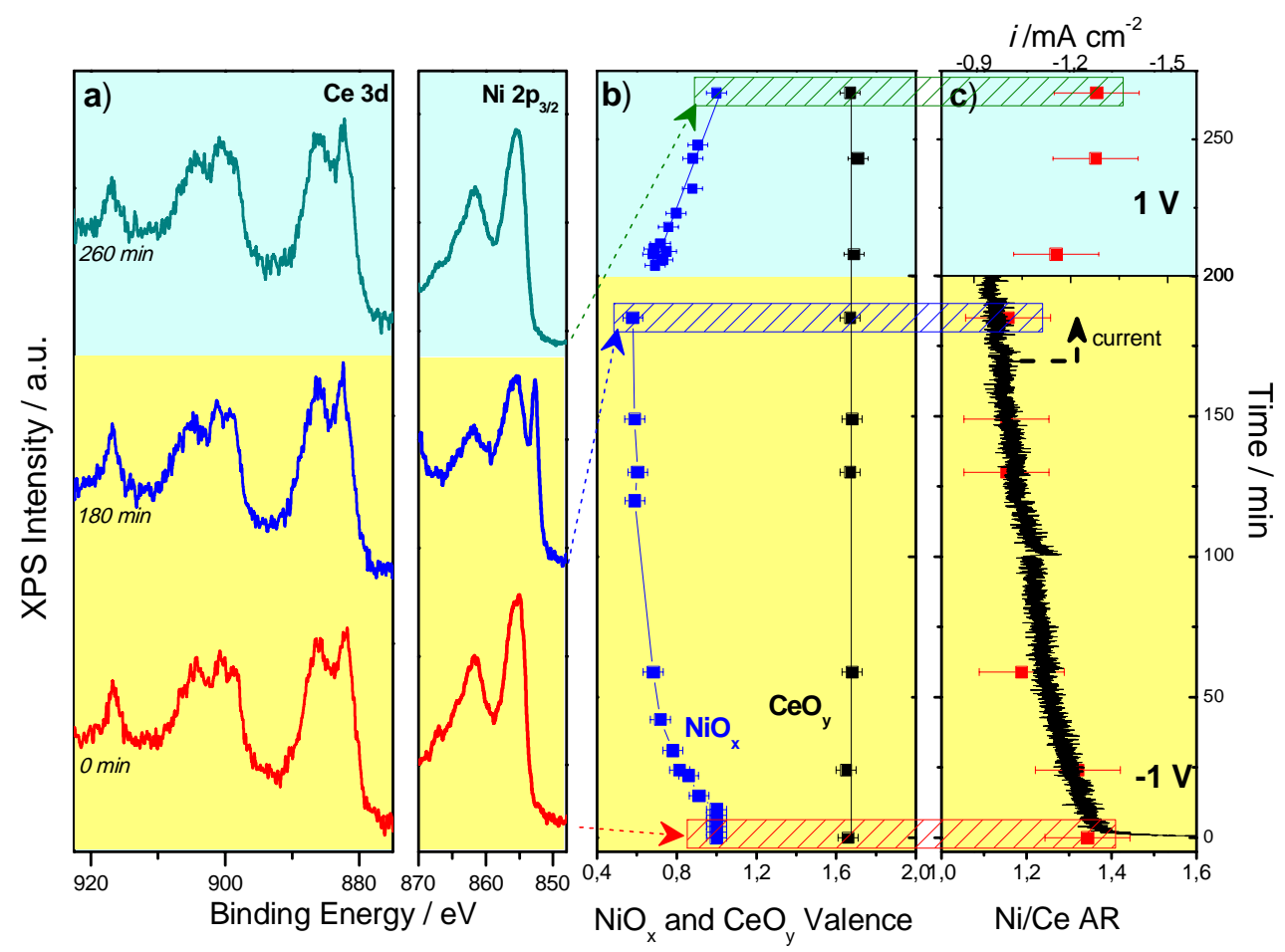

Figure 2. a) The $\mathrm{Ce} 3 \mathrm{~d}$ and $\mathrm{Ni} 2 \mathrm{p} 3 / 2$ spectra, b) The $\mathrm{NiO}_{x}$ and $\mathrm{CeO}_{y}$ stoichiometry and c) $\mathrm{Ni} / \mathrm{Ce}$ AR obtained by APXPS (red squares) as a function of time on stream at $1 \mathrm{~V}$ cathodic (yellow background) and anodic (cyan background) bias at $500^{\circ} \mathrm{C}$ under $0.2 \mathrm{mbar} \mathrm{H} 2 \mathrm{O}$. The cell current density (black line) is also included. Prior to polarization the electrode was reduced in $\mathrm{H} 2$ and equilibrated in steam at $500^{\circ} \mathrm{C}$ and O.C. for 3 hours.

\subsection{Depth profile measurements.}

Depth dependent measurements were performed at the equilibrium conditions (after $120 \mathrm{~min}$ in fig. 2 ) in order to distinguish the arrangement between nickel, ceria and their various oxidation states at the outermost and near-surface layers. At this point it has to be mentioned that the thickness of the examined cathode $(80 \mu \mathrm{m})$, is similar to the commonly used electrodes in various SOFC and SOEC studies. Indicatively, in the case of electrolyte supported cells, the electrodes' thickness ranges between $17 \mu \mathrm{m}$ [52] up to $100 \mu \mathrm{m}$ [53]. Furthermore, the mixed ionic and electron conductor (MIEC) properties of $\mathrm{Ni} / \mathrm{GDC}$ enable $\mathrm{O}^{2-}$ ions and electrons to be transferred through the entire layer of the electrode and even though the electrochemical reaction rate is faster at the interface between the 
electrode and the electrolyte, this does not exclude the fact that the upper surface layers participate and thus are affected by the electrochemical (charge transfer) processes. In figure $3 a$ and $b$ the Ce $3 d$ and $\mathrm{Ni} 2 p_{3 / 2}$ spectra recorded using 2 photon energies as well as reference spectra obtained from the pure phases are shown. The contribution from $\mathrm{CeO}_{1.5}$ and metallic $\mathrm{Ni}$ spectra features are clearly enhanced in the more surface sensitive measurement indicating that $\mathrm{NiO}$ and $\mathrm{CeO}_{2}$ are located in the deeper layers and the surface is dominated by $\mathrm{Ni}$ and $\mathrm{CeO}_{1.5}$ in a core-shell like structure. The segregated reduced ceria surface layer, with its complement oxygen vacancies, is in accordance with previous studies [54]. However, the metallic $\mathrm{Ni}$ shell over $\mathrm{NiO}$ has been reported only for electrochemical reduction of $\mathrm{NiO}$ [49], while for $\mathrm{H}_{2}$-mediated (chemical) reduction the inverse scheme, with a NiO shell over $\mathrm{Ni}$, is sustained [55],[56]. This basic morphological difference reflects the fact that electrochemical and chemical reductions do not follow the same mechanism. In particular, chemical reduction usually proceeds via diffusion of Ni cations into the subsurface, always leaving a NiO shell on the surface [56]. On the other hand, our results suggest that electrochemical reduction takes place by an outward diffusion of $\mathrm{O}$ anions, resulting in the formation of a $\mathrm{Ni}$-shell with a gradually increased thickness.
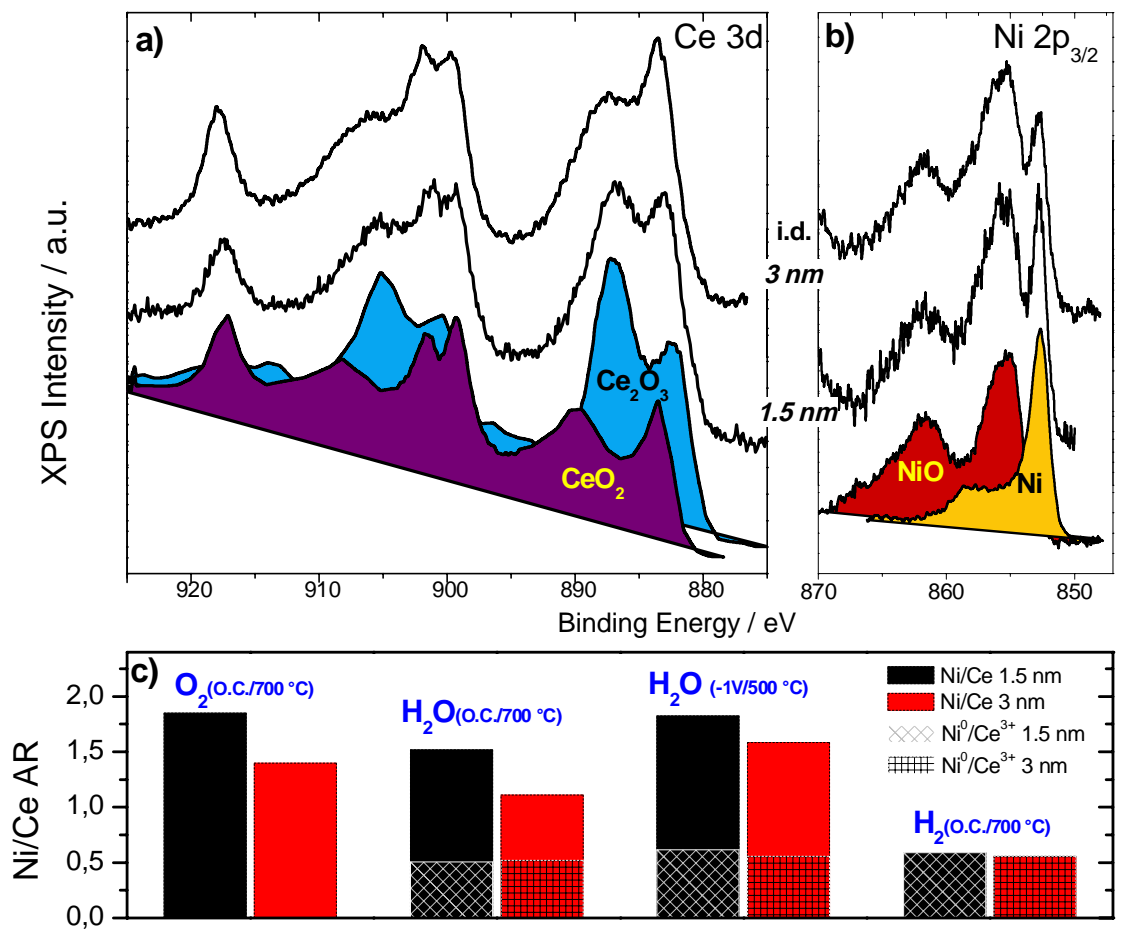

Figure 3. a) $\mathrm{Ce} 3 \mathrm{~d}$ and b) $\mathrm{Ni} 2 \mathrm{p}_{3 / 2}$ APXPS spectra in two information depths (i.d.) under $\mathrm{H}_{2} \mathrm{O}$ at $500^{\circ} \mathrm{C}$ and $-1 \mathrm{~V}$ bias. The reference spectra recorded on $\mathrm{CeO}_{2}, \mathrm{CeO}_{1.5}, \mathrm{NiO}$ and $\mathrm{Ni}$ are shown in the bottom of the graph. $\mathrm{c}$ ) The $\mathrm{Ni} 2 \mathrm{p}$ to $\mathrm{Ce} 3 \mathrm{~d}$ APXPS area ratio of the overall ( $\mathrm{Ni} / \mathrm{Ce}$ ) peak and only the metallic $\mathrm{Ni}$ and $\mathrm{CeO}_{1.5}$ components $\left(\mathrm{Ni}^{0} / \mathrm{Ce}^{3+}\right)$ for the two i.d.s. The conditions where the spectra were recorded are indicated in the graph. 
Fig. $3 c$ shows the ratio of the overall $\mathrm{Ni} 2 \mathrm{p}$ to $\mathrm{Ce} 3 \mathrm{~d}$ peaks $(\mathrm{Ni} / \mathrm{Ce})$ and that of the metallic $\mathrm{Ni}$ and $\mathrm{CeO}_{1.5}$ component in the $\mathrm{Ce} 3 \mathrm{~d}$ spectrum $\left(\mathrm{Ni}^{0} / \mathrm{Ce}^{3+}\right)$ for two information depths (i.ds.) and for various cell conditions. The $\mathrm{Ni} / \mathrm{Ce} \mathrm{AR}$ decreases in more reducing gas phase atmospheres, while it is systematically higher at the $1.5 \mathrm{~nm}$ compared to $3 \mathrm{~nm}$ analysis depth. However, the $\mathrm{Ni}^{\%} / \mathrm{Ce}^{3+} \mathrm{AR}$ remains practically the same in both i.ds. and all conditions, pointing to a homogeneous mixture of the two. With the aid of quantitative simulations we propose a plausible surface model to account for these contradictory observations.

\subsection{Simulation of the XPS Ni/Ce AR.}

In order to quantify the expected modification of the $\mathrm{Ni} / \mathrm{Ce}$ AR upon volume changes of $\mathrm{Ni}$ and ceria particles, quantitative simulation of $\mathrm{Ni} 2 \mathrm{p}$ and Ce $3 \mathrm{~d}$ peak intensities was performed by SESSA vs2.0 software [57] and was compared with the experimental results. Two primary factors can contribute to the changes of $\mathrm{Ni} / \mathrm{Ce}$ ARs, a) the modification in the volume of nickel and ceria particles and $b$ ) the mutual surface segregation among them. It is well-known that reduction of $\mathrm{NiO}$ to $\mathrm{Ni}$ is followed by a significant volume contraction (up to ca. 70\%) [58],[59]. On the contrary, reduction of $\mathrm{CeO}_{2}$ to $\mathrm{CeO}_{1.5}$ is followed by a less pronounced lattice expansion (c.a. 4-9\%) [60],[61], due to the fact the $\mathrm{Ce}^{3+}$ has a larger atomic radius as compared to $\mathrm{Ce}^{4+}[62]$. The reverse tendency is anticipated upon re-oxidation, even if differences from the original volume due to coarsening might occur [58]. Therefore reduced surface states (e.g. metallic $\mathrm{Ni}$ and $\mathrm{CeO}_{1.5}$ ) should correspond to lower $\mathrm{Ni}$ and slightly higher ceria surface areas and accordingly to lower $\mathrm{Ni} / \mathrm{Ce} \mathrm{AR}$, as compared to the oxidized ones.

The simulation showed that the $\mathrm{Ni} / \mathrm{Ce}$ peak intensity ratio measured over non-overlapping spherical nickel and ceria particles (for diameters varying from $50 \mathrm{~nm}$ to 1.6 micro) can be up to 2 times higher in oxidized compared to the reduced form, assuming $50 \%$ volume decrease of $\mathrm{Ni}$ as compared to $\mathrm{NiO}$ and $10 \%$ volume increase of $\mathrm{CeO}_{1.5}$ as compared to $\mathrm{CeO}_{2}$. Therefore, in case of significant volumetric changes of nickel and ceria particles, oxidized electrodes will show higher Ni/Ce ARs as compared to the reduced as is graphically shown in the cartoon in supporting information 7. Therefore, the differences in the overall $\mathrm{Ni} / \mathrm{Ce} \mathrm{AR}$, shown in fig. 3c, can be in principle rationalized by the differences in the reducing efficiency of each environment. However, surface segregation of nickel over ceria can also account for the observed high $\mathrm{Ni} / \mathrm{Ce} \mathrm{AR}$ in the oxidized environment and vice versa for the reduced one.

Depth-dependent measurements can be used to distinguish if modifications of the $\mathrm{Ni} / \mathrm{Ce}$ AR are due to volumetric changes alone, or if they can also be due to mutual surface segregation. Evidently, if nickel and ceria arrange in well separated individual particles (with diameter higher than $3 \mathrm{~nm}$ ) or form a homogeneous surface mixture, the Ni/Ce ratio should not depend on the i.d.. On the contrary, segregation of one electrode constituent over the other should be followed by different $\mathrm{Ni} / \mathrm{Ce}$ ratios 
in the two i.d.. As shown in fig. 3c the Ni/Ce AR is systematically higher in the surface sensitive mode, especially when nickel is (partially) oxidized, which is a strong evidence of $\mathrm{NiO}$ segregation over $\mathrm{CeO}_{2}$. However, this difference fades away when nickel and ceria are further reduced e.g. in $\mathrm{H}_{2}$. Furthermore, the $\mathrm{Ni}^{0} / \mathrm{Ce}^{3+}$ partial ratio remains identical in the two depths independently of the atmosphere and application of the bias voltage (fig. 3c).

Using Sessa vs2.0 we simulated the $\mathrm{Ni} / \mathrm{Ce}$ ratio of five different surface arrangement models between nickel and ceria, including individual core/shell $\mathrm{NiO} / \mathrm{Ni}, \mathrm{CeO}_{2} / \mathrm{CeO}_{1.5}$ particles and a 1:1 mixed $\mathrm{Ni}-\mathrm{CeO}_{1.5}$ layer over $\mathrm{NiO}$ and $\mathrm{CeO}_{2}$ particles (see supporting information 8). The aim of the simulation was to reproduce the experimental trend in both $\mathrm{Ni} / \mathrm{Ce}$ and $\mathrm{Ni}^{\%} / \mathrm{Ce}^{3+} \mathrm{AR}$ as a function of the excitation photon energy (information depth) found for partially oxidized nickel (Fig. 3). The simulation showed that the decrease of the overall $\mathrm{Ni} / \mathrm{Ce}$ ratio when higher photon energy is used can be described by several arrangement models; (for details see supporting information 8). However, among the examined models only two arrangements can also reproduce the identical $\mathrm{Ni}^{0} / \mathrm{Ce}^{3+} \mathrm{AR}$ in the two analysis depths shown in fig. $3 \mathrm{C}$; i) $0.6 \mathrm{~nm} \mathrm{Ni}-\mathrm{CeO}_{1.5}$ 1:1 mixed layer over $\mathrm{CeO}_{2}$ and individual $\mathrm{NiO}$ particles ii) $0.6 \mathrm{~nm} \mathrm{Ni-CeO}{ }_{1.5}$ 1:1 mixed layer over $\mathrm{CeO}_{2}$ and $0.2 \mathrm{~nm} \mathrm{Ni-CeO}{ }_{1.5} 1: 1$ mixed layer over $\mathrm{NiO}$. Note that the calculated layer thickness is not accurate but indicative, since the simulation is influenced by uncertainties in the electrode grains shape and size. In any case, the average $\mathrm{Ni}-\mathrm{CeO}_{1.5}$ layer thickness should be comparable with the analysis depth of the APXPS technique (ca. $<3 \mathrm{~nm}$ ).

\subsection{Surface imaging by scanning electron microscopy.}

Top view SEM images show that the surface of the fresh electrode appears porous in micro-structure with uniformly distributed grains (fig. 4a). Macroscopically there are no significant changes of the morphology after the in-situ treatments (fig. 4b), however high magnification images (insets) show that the microstructure of the particles has been modified. In particular, just after high temperature sintering (inset fig. 4a), the particles appear to have a crystalline form with well-defined edges, while after APXPS measurements the shape of the particles is rounded (inset fig. 4b). This indicates that to a certain extent mass transport between the particles took place during operation without extended macroscopic sintering and agglomeration of the grains. This is also providing indirect evidence of the fact that the interior (bulk) of the electrode grains did not reduce during the APXPS measurements. EDX spectra taken at various samples areas (not shown) show combined features due to $\mathrm{Ce}$ and $\mathrm{Ni}$, but it was not possible to distinguish individual particles of nickel or ceria pointing to well intermixed electrode materials. 


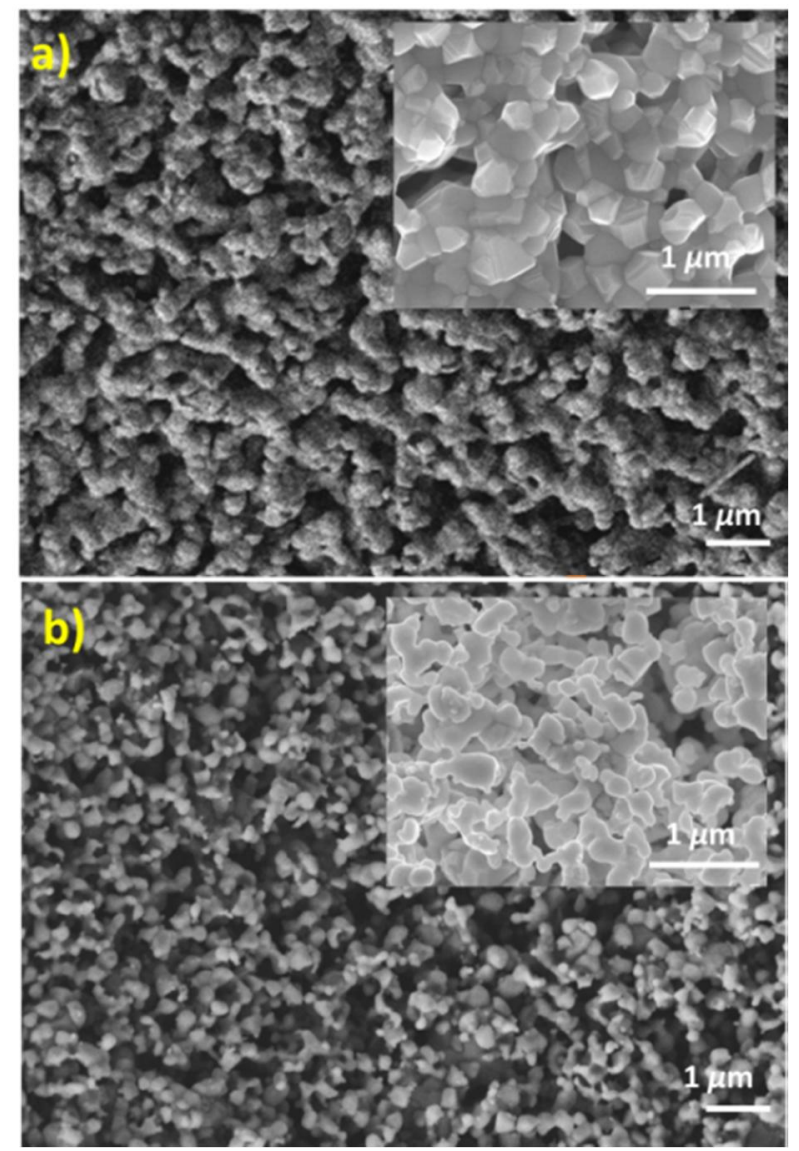

Figure 4. Top view SEM images of the cathode surface in a) fresh state (after sintering at $1250{ }^{\circ} \mathrm{C}$ in atmosphere) and b) after APXPS measurements. The insets show enlarged views of the cathodes morphology.

\section{Discussion}

\subsection{The surface valence state of the electrode elements.}

The presented results showed that both nickel and ceria readily adapt their surface oxidation state to the gas atmosphere, while nickel can be also electrochemically reduced under cathodic polarization. In equilibrium with water vapor nickel is oxidized (eq. 1), but electrolytic NiO reduction (eq. 2) is also observed starting at an applied bias of $-1 \mathrm{~V}$. The examined temperature and low pressure reaction conditions create a dynamic interplay between gas-phase oxidation and potential-driven reduction, the convolution of which determines the actual oxidation state of nickel under water electrolysis. Evidently, the rate of electrochemical reduction is enhanced with the bias voltage, while the thermochemical oxidation rate is stable under identical temperature and pressure conditions.

The interaction of ceria with steam results in a mixed ceria oxidation state $\left(\mathrm{Ce}^{3+/} \mathrm{Ce}^{4+}\right)$, reflecting the co-existence of a variety of ceria surface sites promoting both oxidation and reduction reactions [63],[64],[65]. Water dissociation on stoichiometric $\mathrm{CeO}_{2}$ partially reduces the surface [66], while 
over reduced ceria $\left(\mathrm{CeO}_{1.5}\right)$ surface water molecules interact with oxygen vacancies,[63] and reoxidize ceria. The proposed reaction schemes are the following:

$$
\begin{gathered}
2 \mathrm{Ce}_{(s)}^{4+}+\mathrm{O}_{(s)}^{2-}+\mathrm{H}_{2} \mathrm{O}_{(\mathrm{g})} \neq 2 \mathrm{Ce}_{(s)}^{3+}+\mathrm{O}_{2(\mathrm{~g})}+\mathrm{H}_{2(\mathrm{~g})} \\
2 \mathrm{Ce}_{(s)}^{3+}+\mathrm{H}_{2} \mathrm{O}_{(\mathrm{g})} \neq 2 \mathrm{C} e_{(s)}^{4+}+O_{(s)}^{2-}+\mathrm{H}_{2(\mathrm{~g})}
\end{gathered}
$$

The portion of reduced ceria increases by increasing the reducing potential of the gas phase (e.g. addition of $\mathrm{H}_{2}$, see Table 1 ) however, in contrast to nickel, the oxidation state of ceria does not respond to the applied bias under the employed conditions.

\subsection{The surface morphology.}

The quantitative simulation indicated an ultrathin $\mathrm{Ni}-\mathrm{CeO}_{1.5}$ mixed layer, which stabilizes on the surface of the electrode under the examined mild operational conditions $\left(-1 \mathrm{~V}, 500^{\circ} \mathrm{C}, 0.2 \mathrm{mbar}\right)$. The exact nature of the mixed $\mathrm{Ni}-\mathrm{CeO}_{1.5}$ layer is not yet clear; it might consist of an ordered $\mathrm{Ni}-\mathrm{Ce}$ microstructure due to direct substitution of $\mathrm{Ce}^{3+}$ ions with $\mathrm{Ni}$ as proposed before[67], or alternatively by mixed cubic (Ni) and fluorite (GDC) lattice areas with a high degree of grain boundaries. Two possible mechanisms can elucidate the formation of the proposed mixed $\mathrm{Ni}-\mathrm{CeO}_{1.5}$ surface layer. As shown in fig. $3 \mathrm{CeO}_{2} / \mathrm{NiO}$ core/shell structure is formed in oxidizing environment (e.g. during calcination). In the course of steam electrolysis, metallic $\mathrm{Ni}$ and $\mathrm{Ce}^{3+}$ ions inter-diffuse in a mutual surface zone, which is limited by the thickness of the $\mathrm{Ce}^{3+}$ layer. As explained by Li et al. the relatively large atomic misfit of the $\mathrm{Ni}-\mathrm{Ce}^{4+}$ pair (42.5\%) as compared to $\mathrm{Ni}-\mathrm{Ce}^{3+}(21.6 \%)$, hinders Ni diffusion into the $\mathrm{CeO}_{2}$ core lattice [60],[67]. Alternatively, the $\mathrm{Ni}-\mathrm{CeO}_{1.5}$ surface layer can be directly formed under electrolysis conditions due to volatilization of hydroxide nickel species and re-deposition over ceria.[68] Upon thermal decomposition of nickel oxyhydroxide over $\mathrm{CeO}_{1.5}$ electrode areas, interdiffusion can be anticipated. The present results are supported by previous ex situ microscopy observations on Ni/DGC electrodes under reducing conditions, showing that ceria and metallic nickel can diffuse in their interface in lengths up to $200 \mathrm{~nm}$ [60],[67]. They are also coherent with the modification of the particles morphology after electrolysis, demonstrated in the high resolution SEM images (fig.4). However, as we show in this work the electrode surface state is dynamic and likely to vary when the operation conditions (gas, temperature, potential) are modified. Therefore one should be cautious when performs post-mortem analysis of the samples, for example using high resolution microscopy. Unfortunately, to our knowledge environmental TEM instruments able to study complex ceramic electrodes at high temperatures and under electrochemical operation are not yet available.

\subsection{Correlation of the electrochemical performance with nickel oxidation state.}

B.W. Eichhorn and co-workers [29] determined the electrochemically active region in water electrolysis and found that extents at about $150 \mu \mathrm{m}$ from the current collector. Since the thickness of 
our NiGDC electrode is about $80 \mu \mathrm{m}$, the outer $5 \mathrm{~nm}$ probed by the AP-XPS and NEXAFS methods are definitely in the electrochemical reaction zone of the working electrode and therefore representative to the NiGDC electrode state. Therefore, the ability of partially oxidized nickel electrode to maintain higher cell currents as compared to metallic nickel is a direct consequence of the surface arrangement. As shown in the cartoon of fig. 5, when the calcined electrode is exposed in oxidative fuel operation conditions i.e. $100 \%$ steam, a thin skin of mixed nickel and $\mathrm{CeO}_{1.5}$ dominates the surface. The surface skin layer provides an enhanced number of Ni-GDC contact areas (TPBs), thus increasing electronic/ionic conductivity and the electrochemical reaction sites. At the same time it can be suggested that the interior $\mathrm{NiO}$ core enables nickel particles to keep their increased volume and consequently retards the process of nickel coarsening. At high polarization voltages, the electrolytic NiO reduction rate is enhanced and the reduced surface layer becomes thicker. In this case the $\mathrm{NiO}$ core is not directly evident in the $\mathrm{Ni} 2 \mathrm{p}$ spectra due to the high surface sensitivity of APXPS. However, its presence is indirectly manifested by the relatively high $\mathrm{Ni} / \mathrm{Ce}$ ARs (fig. $1 \mathrm{C}$ ). $\mathrm{H}_{2} /$ $\mathrm{H}_{2} \mathrm{O}$ mixture or $\mathrm{H}_{2}$ atmosphere, the reduction of $\mathrm{NiO}$ extends into the bulk and induces the contraction of the nickel particles volume, as confirmed by the systematically lower $\mathrm{Ni} / \mathrm{Ce}$ ARs compared to $100 \%$ steam (Table 1). Therefore, the available TPB length is reduced resulting in the decrease of the current density.

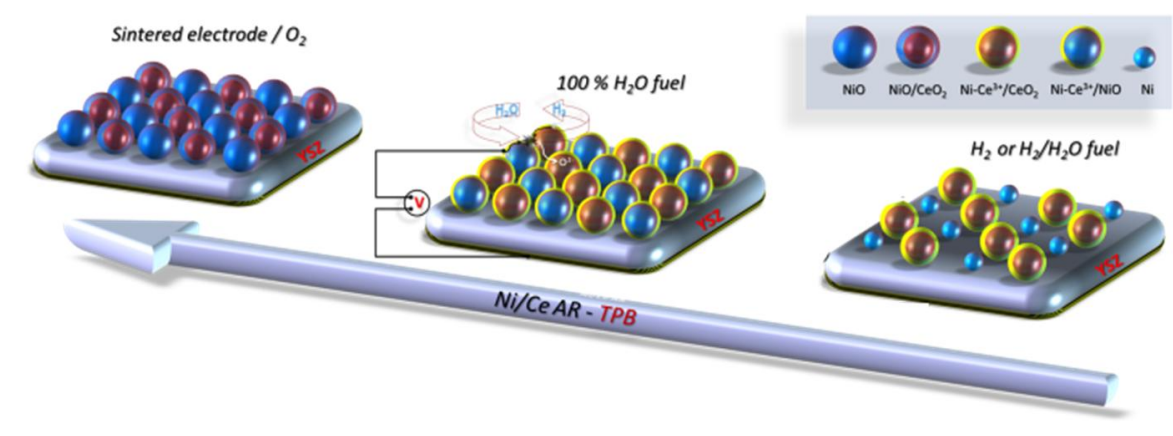

Figure 5. Schematic representation of the proposed nickel and ceria surface arrangement under different operation conditions. For clarity the nickel and ceria grains are represented by a single layer of spherical core/shell particles symmetrically arranged over the YSZ electrolyte. For a more representative image of the surface morphology please refer to fig. 4 .

Currently most of the efforts to improve the performance of solid oxide electrodes are focusing on the development of suitable materials [69]. In a different approach, Mogensen and co-workers recently proposed to eliminate degradation phenomena on solid oxide cells by implementing reversible fuel/electrolysis cell operation conditions [8]. Our experiments have analyzed the outermost surface layers of a working Ni-based SOEC electrode, providing details of the complex morphological and chemical modifications during operation. We show that the electrode surface dynamically responds to the fuel feed and the applied potential, while we establish a correlation 
between nickel oxidation state and TPB. This knowledge might be used to introduce a new concept for SOEC improvement strategies. One can envisage the use of conventional electrode materials, focusing on the optimization of the cells 'operational parameters. The aim is operate the cells under such experimental conditions, where there is stabilization of the typically transient surface configurations, instead of those surface arrangements that are usually present. The former might prove to be more active and/or durable, than those that are commonly detected. As an example we show that under the examined reaction conditions of this study, the maintenance of nickel grains in a partially oxidized state, might be advantageous.

\section{Conclusions}

In summary, the surface state of the Ni/GDC electrode in a SOEC cell was investigated upon electrolysis of $\mathrm{H}_{2} \mathrm{O}$ by means of APXPS and NEXAFS spectroscopies. It was shown that the oxidation state and composition is dynamic and adapts to the fuel and the applied voltage. In oxidative environments surface segregation of oxidized nickel over ceria particles is observed, while under specific operational conditions nickel is maintained in a partially oxidized state. In that case, one can anticipate a core-shell surface morphology consisting of a surface $\mathrm{Ni}-\mathrm{CeO}_{1.5}$ skin and an interior NiO$\mathrm{CeO}_{2}$ backbone. The reduced surface shell maintains the high electronic conductivity and the appropriate TPB length for the water electrolysis reaction, whereas the oxidized core helps to maintain the particles volume and thus sustains the microstructure of the electrode.

\section{Acknowledgements}

The research leading to these results has received funding from the Fuel Cells and Hydrogen 2 Joint Undertaking under the project SElySOs with grant agreement No 671481. This Joint Undertaking receives support from the European Union's Horizon 2020 research and innovation programme and Greece, Germany, Czech Republic, France, Norway. We thank Dr. T. Dintzer for his help with the SEM images and Dr. S. Neophytides for his useful and constructive comments. Finally, we acknowledge $\mathrm{HZB}$ for the allocation of synchrotron radiation beamtime.

\section{References}

[1] M. Wang, Z. Wang, X. Gong, Z. Guo, The intensification technologies to water electrolysis for hydrogen production - A review, Renewable \&amp; Sustainable Energy Reviews, 29 (2014) 573-588. [2] M. Gong, W. Zhou, M.-C. Tsai, J. Zhou, M. Guan, M.-C. Lin, B. Zhang, Y. Hu, D.-Y. Wang, J. Yang, S.J . Pennycook, B.-J. Hwang, H. Dai, Nanoscale nickel oxide/nickel heterostructures for active hydrogen evolution electrocatalysis, Nature Communications, 5 (2014). 
[3] L. Zeng, T.S. Zhao, Integrated inorganic membrane electrode assembly with layered double hydroxides as ionic conductors for anion exchange membrane water electrolysis, Nano Energy, 11 (2015) 110-118.

[4] M.A. Laguna-Bercero, Recent advances in high temperature electrolysis using solid oxide fuel cells: A review, Journal of Power Sources, 203 (2012) 4-16.

[5] F. Petipas, A. Brisse, C. Bouallou, Benefits of external heat sources for high temperature electrolyser systems, International Journal of Hydrogen Energy, 39 (2014) 5505-5513.

[6] L. Bi, S. Boulfrad, E. Traversa, Steam electrolysis by solid oxide electrolysis cells (SOECs) with proton-conducting oxides, Chemical Society Reviews, 43 (2014) 8255-8270.

[7] A. Brisse, J. Schefold, M. Zahid, High temperature water electrolysis in solid oxide cells, International Journal of Hydrogen Energy, 33 (2008) 5375-5382.

[8] C. Graves, S.D. Ebbesen, S.H. Jensen, S.B. Simonsen, M.B. Mogensen, Eliminating degradation in solid oxide electrochemical cells by reversible operation, Nature Materials, 14 (2015) 239-244.

[9] Z.P. Jovanov, H.A. Hansen, A.S. Varela, P. M alacrida, A.A. Peterson, J.K. Norskov, I.E.L. Stephens, I. Chorkendorff, Opportunities and challenges in the electrocatalysis of $\mathrm{CO} 2$ and $\mathrm{CO}$ reduction using bifunctional surfaces: A theoretical and experimental study of Au-Cd alloys, Journal of Catalysis, 343 (2016) 215-231.

[10] M. Ni, M.K.H. Leung, D.Y.C. Leung, Technological development of hydrogen production by solid oxide electrolyzer cell (SOEC), International Journal of Hydrogen Energy, 33 (2008) 2337-2354.

[11] A.J. Jacobson, M aterials for Solid Oxide Fuel Cells, Chemistry of Materials, 22 (2010) 660-674.

[12] M. Mogensen, N.M. Sammes, G.A. Tompsett, Physical, chemical and electrochemical properties of pure and doped ceria, Solid State Ionics, 129 (2000) 63-94.

[13] K. Yamamoto, T. Hashishin, M. Matsuda, N. Qiu, Z. Tan, S. Ohara, High-performance Ni nanocomposite anode fabricated from Gd-doped ceria nanocubes for low-temperature solid-oxide fuel cells, Nano Energy, 6 (2014) 103-108.

[14] W.C. Chueh, A.H. M cDaniel, M.E. Grass, Y. Hao, N. Jabeen, Z. Liu, S.M. Haile, K.F. M cCarty, H. Bluhm, F. El Gabaly, Highly Enhanced Concentration and Stability of Reactive Ce3+ on Doped CeO2 Surface Revealed In Operando, Chemistry of Materials, 24 (2012) 1876-1882.

[15] G. Di Giuseppe, J.R. Selman, Anode-supported planar solid oxide fuel cells by plasma-enhanced metalorganic chemical vapor deposition (PE-MOCVD) and electrostatic spray deposition (ESD): Fabrication of dense thin layers of yttria-stabilized zirconia by PE-MOCVD, Journal of Materials Research, 16 (2001) 2983-2991.

[16] Y. Sunagawa, K. Yamamoto, A. M uramatsu, Improvement in SOFC anode performance by finelystructured $\mathrm{Ni} / \mathrm{YSZ}$ cermet prepared via heterocoagulation, Journal of Physical Chemistry $\mathrm{B}, 110$ (2006) 6224-6228.

[17] P. Kim-Lohsoontorn, J. Bae, Electrochemical performance of solid oxide electrolysis cell electrodes under high-temperature coelectrolysis of steam and carbon dioxide, Journal of Power Sources, 196 (2011) 7161-7168.

[18] P. Kim-Lohsoontorn, Y.-M. Kim, N. Laosiripojana, J. Bae, Gadolinium doped ceria-impregnated nickel-yttria stabilised zirconia cathode for solid oxide electrolysis cell, International Journal of Hydrogen Energy, 36 (2011) 9420-9427.

[19] H. Yokokawa, H. Tu, B. Iwanschitz, A. Mai, Fundamental mechanisms limiting solid oxide fuel cell durability, Journal of Power Sources, 182 (2008) 400-412.

[20] A. Faes, A. Hessler-Wyser, A. Zryd, J. Van Herle, A Review of RedOx Cycling of Solid Oxide Fuel Cells Anode, M embranes, 2 (2012) 585-664.

[21] D. Sarantaridis, A. Atkinson, Redox cycling of Ni-based solid oxide fuel cell anodes: A review, Fuel Cells, 7 (2007) 246-258.

[22] M. Ettler, H. Timmermann, J. Malzbender, A. Weber, N.H. Menzler, Durability of Ni anodes during reoxidation cycles, Journal of Power Sources, 195 (2010) 5452-5467.

[23] F. Tietz, D. Sebold, A. Brisse, J. Schefold, Degradation phenomena in a solid oxide electrolysis cell after 9000 h of operation, Journal of Power Sources, 223 (2013) 129-135. 
[24] D. The, S. Grieshammer, M. Schroeder, M. Martin, M. Al Daroukh, F. Tietz, J. Schefold, A. Brisse, M icrostructural comparison of solid oxide electrolyser cells operated for $6100 \mathrm{~h}$ and $9000 \mathrm{~h}$, Journal of Power Sources, 275 (2015) 901-911.

[25] A. Banerjee, O. Deutschmann, Elementary kinetics of the oxygen reduction reaction on LSM-YSZ composite cathodes, Journal of Catalysis, 346 (2017) 30-49.

[26] S. Souentie, M. Athanasiou, D.K. Niakolas, A. Katsaounis, S.G. Neophytides, C.G. Vayenas, Mathematical modeling of $\mathrm{Ni} / \mathrm{GDC}$ and Au-Ni/GDC SOFC anodes performance under internal methane steam reforming conditions, Journal of Catalysis, 306 (2013) 116-128.

[27] L. Zhu, B. Wei, Z.H. Wang, K.F. Chen, H.W. Zhang, Y.H. Zhang, X.Q. Huang, Z. Lue, Electrochemically Driven Deactivation and Recovery in PrBaC0205+Oxygen Electrodes for Reversible Solid Oxide Fuel Cells, Chemsuschem, 9 (2016) 2443-2450.

[28] C. Zhang, M.E. Grass, Y. Yu, K.J. Gaskell, S.C. DeCaluwe, R. Chang, G.S. Jackson, Z. Hussain, H. Bluhm, B.W. Eichhorn, Z. Liu, Multielement Activity Mapping and Potential Mapping in Solid Oxide Electrochemical Cells through the use of operando XPS, Acs Catalysis, 2 (2012) 2297-2304.

[29] C. Zhang, M.E. Grass, A.H. McDaniel, S.C. DeCaluwe, F. El Gabaly, Z Liu, K.F. M cCarty, R.L. Farrow, M.A. Linne, Z. Hussain, G.S. Jackson, H. Bluhm, B.W. Eichhorn, Measuring fundamental properties in operating solid oxide electrochemical cells by using in situ X-ray photoelectron spectroscopy, Nature Materials, 9 (2010) 944-949.

[30] C. Zhang, Y. Yu, M.E. Grass, C. Dejoie, W. Ding, K. Gaskell, N. Jabeen, Y.P. Hong, A. Shayorskiy, H. Bluhrn, W.-X. Li, G.S. Jackson, Z. Hussain, Z. Liu, B.W. Eichhorn, Mechanistic Studies of Water Electrolysis and Hydrogen Electro-Oxidation on High Temperature Ceria-Based Solid Oxide Electrochemical Cells, Journal of the American Chemical Society, 135 (2013) 11572-11579.

[31] S.C. DeCaluwe, M.E. Grass, C. Zhang, F. El Gabaly, H. Bluhm, Z Liu, G.S. Jackson, A.H. M cDaniel, K.F. M cCarty, R.L. Farrow, M.A. Linne, Z. Hussain, B.W. Eichhorn, In Situ Characterization of Ceria Oxidation States in High-Temperature Electrochemical Cells with Ambient Pressure XPS, Journal of Physical Chemistry C, 114 (2010) 19853-19861.

[32] Z.A. Feng, F. El Gabaly, X. Ye, Z.-X. Shen, W.C. Chueh, Fast vacancy-mediated oxygen ion incorporation across the ceria-gas electrochemical interface, Nature Communications, 5 (2014) 43744374.

[33] Q. Chen, F. El Gabaly, F.A. Akgul, Z. Liu, B.S. Mun, S. Yamaguchi, A. Braun, Observation of Oxygen Vacancy Filling under Water Vapor in Ceramic Proton Conductors in Situ with Ambient Pressure XPS, Chemistry of M aterials, 25 (2013) 4690-4696.

[34] F. El Gabaly, K.F. M cCarty, H. Bluhm, A.H. McDaniel, Oxidation stages of Ni electrodes in solid oxide fuel cell environments, Physical Chemistry Chemical Physics, 15 (2013) 8334-8341.

[35] V. Papaefthimiou, M. Shishkin, D.K. Niakolas, M. Athanasiou, Y.T. Law, R. Arrigo, D. Teschner, M. Haevecker, A. Knop-Gericke, R. Schloegl, T. Ziegler, S.G. Neophytides, S. Zafeiratos, On the Active Surface State of Nickel-Ceria Solid Oxide Fuel Cell Anodes During Methane Electrooxidation, Advanced Energy M aterials, 3 (2013) 762-769.

[36] M. Al Daroukh, F. Tietz, D. Sebold, H.P. Buchkremer, Post-test analysis of electrode-supported solid oxide electrolyser cells, lonics, 21 (2015) 1039-1043.

[37] V. Papaefthimiou, D.K. Niakolas, F. Paloukis, T. Dintzer, S. Zafeiratos, Is Steam an Oxidant or a Reductant for Nickel/Doped-Ceria Cermets?, Chemphyschem : a European journal of chemical physics and physical chemistry, 18 (2017) 164-170.

[38] D.K. Niakolas, J.P. Ouweltjes, G. Rietveld, V. Dracopoulos, S.G. Neophytides, Au-doped Ni/GDC as a new anode for SOFCs operating under rich $\mathrm{CH}(4)$ internal steam reforming, International Journal of Hydrogen Energy, 35 (2010) 7898-7904.

[39] A. Knop-Gericke, E. Kleimenov, M. Haevecker, R. Blume, D. Teschner, S. Zafeiratos, R. Schloegl, V.I. Bukhtiyarov, V.V. Kaichev, I.P. Prosvirin, A.I. Nizovskii, H. Bluhm, A. Barinov, P. Dudin, M. Kiskinova, X-Ray Photoelectron Spectroscopy for Investigation of Heterogeneous Catalytic Processes, Advances in Catalysis, Vol 52, 52 (2009) 213-272.

[40] W.S. W.S.M. Werner, C. J. Powell, NIST Database for the Simulation of Electron Spectra for Surface Analysis, in: NIST (Ed.), Gaithersburg, Maryland, 2014. 
[41] J.J. Yeh, I. Lindau, ATOMIC SUBSHELL PHOTOIONIZATION CROSS-SECTIONS AND ASYM METRY PARAMETERS - 1 LESS-THAN-OR-EQUAL-TO Z LESS-THAN-OR-EQUAL-TO 103, Atomic Data and Nuclear Data Tables, 32 (1985) 1-155.

[42] C. Arrive, T. Delahaye, O. Joubert, G. Gauthier, Exsolution of nickel nanoparticles at the surface of a conducting titanate as potential hydrogen electrode material for solid oxide electrochemical cells, Journal of Power Sources, 223 (2013) 341-348.

[43] H.P. Dasari, S.-Y. Park, J. Kim, J.-H. Lee, B.-K. Kim, H.-J. Je, H.-W. Lee, K.J. Yoon, Electrochemical characterization of $\mathrm{Ni}$-yttria stabilized zirconia electrode for hydrogen production in solid oxide electrolysis cells, Journal of Power Sources, 240 (2013) 721-728.

[44] J.P. Neidhardt, R.J. Kee, W.G. Bessler, Electrode Reoxidation in Solid-Oxide Cells: Detailed M odeling of Nickel Oxide Film Growth, Solid Oxide Fuel Cells 13 (Sofc-Xiii), 57 (2013) 2573-2582.

[45] R.J.O. Mossanek, G. Dominguez-Canizares, A. Gutierrez, M. Abbate, D. Diaz-Fernandez, L. Soriano, Effects of $\mathrm{Ni}$ vacancies and crystallite size on the $\mathrm{O} 1 \mathrm{~s}$ and $\mathrm{Ni} 2 \mathrm{p}$ x-ray absorption spectra of nanocrystalline NiO, Journal of Physics-Condensed Matter, 25 (2013).

[46] K. Kleiner, J. M elke, M. M erz, P. Jakes, P. Nagel, S. Schuppler, V. Liebau, H. Ehrenberg, Unraveling the Degradation Process of LiNi0.8C00.15AI0.0502 Electrodes in Commercial Lithium Ion Batteries by Electronic Structure Investigations, Acs Applied M aterials \& Interfaces, 7 (2015) 19589-19600.

[47] B.P. Payne, M.C. Biesinger, N.S. M clntyre, The study of polycrystalline nickel metal oxidation by water vapour, Journal of Electron Spectroscopy and Related Phenomena, 175 (2009) 55-65.

[48] A.G. Marrani, V. Novelli, S. Sheehan, D.P. Dowling, D. Dini, Probing the Redox States at the Surface of Electroactive Nanoporous NiO Thin Films, Acs Applied Materials \&amp; Interfaces, 6 (2014) 143-152.

[49] Q. Hu, T. Jacobsen, K.V. Hansen, M. Mogensen, Electrochemical reduction of NiO in a composite electrode, Solid State Ionics, 234 (2013) 1-10.

[50] W.S.M. Werner, M. Chudzicki, W. Smekal, C.J. Powell, Interpretation of nanoparticle X-ray photoelectron intensities, Applied Physics Letters, 104 (2014).

[51] H. Kuipers, H.C.E. Vanleuven, W.M. Visser, THE CHARACTERIZATION OF HETEROGENEOUS CATALYSTS BY XPS BASED ON GEOM ETRICAL-PROBABILITY .1. MONOMETALIC CATALYSTS, Surface and Interface Analysis, 8 (1986) 235-242.

[52] T. Hibino, A. Hashimoto, M. Suzuki, M. Yano, S. Yoshida, M. Sano, A solid oxide fuel cell with a novel geometry that eliminates the need for preparing a thin electrolyte film, Journal of the Electrochemical Society, 149 (2002) A195-A200.

[53] A. Singh, J.M. Hill, Carbon tolerance, electrochemical performance and stability of solid oxide fuel cells with Ni/yttria stabilized zirconia anodes impregnated with Sn and operated with methane, Journal of Power Sources, 214 (2012) 185-194.

[54] S. Kato, M. Ammann, T. Huthwelker, C. Paun, M. Lampimaeki, M.-T. Lee, M. Rothensteiner, J.A. van Bokhoven, Quantitative depth profiling of $\mathrm{Ce} 3+$ in $\mathrm{Pt} / \mathrm{CeO} 2$ by in situ high-energy XPS in a hydrogen atmosphere, Physical Chemistry Chemical Physics, 17 (2015) 5078-5083.

[55] J.A. Medford, A.C. Johnston-Peck, J.B. Tracy, Nanostructural transformations during the reduction of hollow and porous nickel oxide nanoparticles, Nanoscale, 5 (2013) 155-159.

[56] S. Chenna, P.A. Crozier, In situ environmental transmission electron microscopy to determine transformation pathways in supported Ni nanoparticles, Micron, 43 (2012) 1188-1194.

[57] W. Smekal, W.S.M. Werner, C.J. Powell, Simulation of electron spectra for surface analysis (SESSA): a novel software tool for quantitative Auger-electron spectroscopy and X-ray photoelectron spectroscopy, Surface and Interface Analysis, 37 (2005) 1059-1067.

[58] A. Faes, Q. Jeangros, J.B. Wagner, T.W. Hansen, J. Van Herle, A. Brisse, R. Dunin-Borkowski, A. Hessler-Wyser, In situ Reduction and Oxidation of Nickel from Solid Oxide Fuel Cells in a Transmission Electron Microscope, Solid Oxide Fuel Cells 11 (Sofc-Xi), 25 (2009) 1985-1992.

[59] F.S. Torknik, M. Keyanpour-Rad, A. Maghsoudipour, G.M. Choi, Effect of microstructure refinement on performance of $\mathrm{Ni} / \mathrm{Ce} 0.8 \mathrm{Gd} 0.201 .9$ anodes for low temperature solid oxide fuel cell, Ceramics International, 40 (2014) 1341-1350. 
[60] Z-P. Li, T. M ori, G.J. Auchterlonie, Y. Guo, J. Zou, J. Drennan, M. Miyayama, M utual Diffusion and $M$ icrostructure Evolution at the Electrolyte-Anode Interface in Intermediate Temperature Solid Oxide Fuel Cell, Journal of Physical Chemistry C, 115 (2011) 6877-6885.

[61] J.L.F. Da Silva, Stability of the Ce2O3 phases: A DFT+U investigation, Physical Review B, 76 (2007).

[62] J. Liu, K. Ye, K. Cheng, G. Wang, J. Yin, D. Cao, The catalytic effect of CeO2 for electrochemical oxidation of graphite in molten carbonate, Electro chimica Acta, 135 (2014) 270-275.

[63] J. Paier, C. Penschke, J. Sauer, Oxygen Defects and Surface Chemistry of Ceria: Quantum Chemical Studies Compared to Experiment, Chemical Reviews, 113 (2013) 3949-3985.

[64] M. Molinari, S.C. Parker, D.C. Sayle, M.S. Islam, Water Adsorption and Its Effect on the Stability of Low Index Stoichiometric and Reduced Surfaces of Ceria, Journal of Physical Chemistry C, 116 (2012) 7073-7082.

[65] M .A. Henderson, C.L. Perkins, M.H. Engelhard, S. Thevuthasan, C.H.F. Peden, Redox properties of water on the oxidized and reduced surfaces of CeO2(111), Surface Science, 526 (2003) 1-18.

[66] B. Chen, Y. Ma, L. Ding, L. Xu, Z. Wu, Q. Yuan, W. Huang, Reactivity of Hydroxyls and Water on a CeO2(111) Thin Film Surface: The Role of Oxygen Vacancy, Journal of Physical Chemistry C, 117 (2013) 5800-5810.

[67] Z.-P. Li, T. M ori, G.J. Auchterlonie, J. Zou, J. Drennan, Superstructure formation and variation in Ni-GDC cermet anodes in SOFC, Physical Chemistry Chemical Physics, 13 (2011) 9685-9690.

[68] A. Hauch, S.D. Ebbesen, S.H. Jensen, M. Mogensen, Solid Oxide Electrolysis Cells: M icrostructure and Degradation of the Ni/Yttria-Stabilized Zirconia Electrode, Journal of the Electrochemical Society, 155 (2008) B1184-B1193.

[69] N. Mahato, A. Banerjee, A. Gupta, S. Omar, K. Balani, Progress in material selection for solid oxide fuel cell technology: A review, Progress in M aterials Science, 72 (2015) 141-337. 